\title{
Securitization and desecuritization of Russia in the national security and defence concepts of Latvia (1995-2020)
}

\author{
Māris Andžāns \\ Riga Stradinš University, Riga, Latvia; \\ Latvian Institute of International Affairs, Riga, Latvia \\ maris.andzans@rsu.lv \\ ORCID 0000-00024695-3929 \\ Andris Sprūds \\ Riga Stradings University, Riga, Latvia \\ Latvian Institute of International Affairs, Riga, Latvia \\ andris.spruds@,rsu.w \\ ORCID 0000-0002-8645-2109
}

\begin{abstract}
This article revisits and applies the securitization theory in assessing securitization and desecuritization of Russia in the national security and state defence concepts of Latvia. The analysis covers the editions of concepts from 1995 up to the date. With the benefit of the quantitative and qualitative content analyses, all mentions of Russia in those fourteen documents are classified as either securitizing, desecuritizing or nonsecuritizing. Further, they are analysed in the wider picture of national security. It is concluded that most of Latvia's national security and state defence documents have reflected the perception of the existent security situation, and they have been limited in their pre-emptive and future-proof nature, at least regarding Russia. In most of the editions of the documents prior to the 2014 Ukraine crisis, Russia has been essentially undersecuritized as compared to the then existing potential of risks and threats. Meanwhile, the final editions from 2015 and on hint that Russia might be oversecuritized - not least compared to the earlier documents, but also at the expense of securitizing other objective threats.
\end{abstract}

Keywords: securitization, desecuritization, national security, Latvia, Russia.

JEL Classification: F52

Received: March, 2020 1st Revision:

May, 2020

Accepted:

March, 2021

DOI:

10.14254/20718330.2021/14-1/13 


\section{INTRODUCTION}

Securitization theory has come a long way since it was first coined and developed by Ole Wæver of the Copenhagen School of International Relations. The approach to securitization has been widely addressed and further developed from various theoretical and methodological angles. It has also been vastly employed in the variety of empirical studies aiming at uncovering the construction and the deconstruction of security processes and strategic security narratives. The analysis of securitization and desecuritization also allows reflecting upon and understanding the underlying causes and dynamics of national security and defence preferences and conceptual formulation.

This article applies the securitization theory to the analysis of almost three decades of evolving national security and state defence concepts in Latvia. More specifically, the aim of this study is to analyse the trends of securitization and desecuritization of Russia in the documents that outline the basic assumptions and actions to be taken regarding the national security and state defence of Latvia. Such analysis of Russia in the national security and state defence policy of Latvia provides a peculiar case for study. On the one hand, it is indeed common knowledge that both countries had and still have uneasy relations and that Russia is seen as the main source of risks to Latvian national security. On the other hand, relations between both have been more complex than that, having fluctuated over the past three decades. With the approach employed in this study, it also offers a different \& structured perspective of Latvia's perception of Russia during the almost three decades in question.

In order to achieve the aim, first, the theory of securitization has to be reviewed. Based on the review of the theoretical aspects to be employed in analysis, a background of the national security and defence concepts of Latvia has to be outlined. Further, the methodological outlook for building the conceptual apparatus, i.e., classifying and explaining securitization and desecuritization moves towards Russia in a wider national security and state defence environment has to be provided. Finally, national security and state defence planning documents have to be vetted, and securitization and desecuritization processes have to be traced there.

Given the aforementioned tasks, this study is structured in three main sections, the introduction and the results \& conclusions. The second section proceeds with a review of the securitization theory, focusing on the structure of securitization and desecuritization processes. The third section builds the empirical part by assessing and contextualizing the national security and state defence planning documents of Latvia. The fourth section, comprising the discussion, provides the methodological framework for an in-depth analysis of the related documents. Further, with the help of quantitative and qualitative content analyses, it reviews all national security and state defence concepts of Latvia in the period from 1995 to 2020, i.e., from the first to the current ones. In particular, it looks into the dynamics, the frequency and the way Russia has been invoked in the basic security and defence documents. It seeks to uncover what factors have underpinned the securitization and desecuritization moves. Furthermore, given the assumption of the Copenhagen School that securitization is intersubjective, the article also seeks to assess if Russia has been oversecuritized or undersecuritized in the contextual setting.

\section{THE THEORETICAL APPROACH - CONSTRUCTION AND DECONSTRUCTION OF SECURITY ISSUES IN TERMS OF SECURITIZATION AND DESECURITIZATION}

The theory of securitization seeks to explain as to how ordinary or non-security issues become security issues, and the opposite process - how security issues become non-security issues. In other words, it provides a structured framework for analysis on how and why certain issues become or do not become security issues, as well as to who and why stands behind such processes. The theory was first outlined and 
developed by Wæver in the end of 1980s and later on (e.g., Wæver, 1989; Wæver, 1995). It was most authoritatively and clearly articulated by Wæver, Barry Buzan and Jaap de Wilde in their collaborative work of 1998 (Buzan et al., 1998). The later work serves in this article as the central point for conceptual reference of the main elements of the theory.

Securitization and desecuritization processes can either succeed or fail. Success depends on various actors and factors. Ultimately, it is the audience (usually - domestic society, though it can be another group, depending on the type of the security issue and the level of analysis) that determines success of the securitization process. If the audience accepts presentation of a referent object (usually - state, though it can be another subject) as existentially threatened, the referent object is considered as existentially threatened. Thus, it becomes a security issue, paving way for exceptional measures to mitigate the threat. If securitization fails, the process concludes as a securitizing move. The referent object is securitized by a securitizing actor, such as state institutions, politicians or interest groups (the securitizing actor can securitize itself, as it often happens with states via their representatives). Success or failure of securitization depends also on the facilitating conditions and functional actors, especially to the influence and position of the securitizer and other actors involved in the process (Buzan et al., 1998, p.21.-42).

In the traditional sense of the theory, securitization is conducted via a speech act (Buzan et al., 1998, p.26). The focus on verbal expression has been confronted from the methodological position, given that certain issues that objectively would be security issues cannot be articulated as such because of the inability of some referent objects or others to securitize them (Hansen, 2000, p.287). Also, other forms of expression of securitization have been suggested - such as the visual securitisation where visuals substitute verbal expressions (Hansen, 2011, p.68-69), (physical) action when something is done instead of or before verbal articulation (Wilkinson, 2007, p.21-22), or bureaucratic proceedings (McDonald, 2008, p.568-569).

Desecuritization, less studied compared to securitization, is normatively favoured by the Copenhagen School because issues should preferably be resolved as a part of ordinary politics (Buzan et al., 1998, p.29). Yet, according to others, a mere preference to desecuritization might solely subdue the issue, but not fix it (as summarized by Buzan \& Hansen, 2009, p.217). Desecuritization itself does not necessarily need to be conducted by limiting the security language on the relevant issue (Wæver, 1995, p.60). As summarized by Paul Roe, it can also take place either by managing or transforming the security issue (Roe, 2004, p.285). The management option is a reference to Wæver, i.e., retaining an issue in security realm but averting security dilemmas and similar concussions (Wæver, 2000, p.253), whereas the transformation option is about bringing the security issue out of the security realm to the ordinary politics (Roe, 2004, p.285) and making it a a-security issue (Ibid; Wæver, 1998, p.81).

\section{THE CONTEXTUAL BACKGROUND - NATIONAL SECURITY AND DEFENCE CONCEPTS AND LATVIA}

In the context of national security, as far as it is understood as state security, it is relatively easy to determine and analyse securitizing actors. Typically, it is clearly defined who is authorized to speak and act for a state. Though, things can get more complicated with nations as referent objects. Also, other actors can rightfully speak and act on their behalf (Buzan et al., 1998, p.41-42).

In the case of Latvia, national security is defined in a broad and long manner. Nevertheless, the definition principally focuses on security of state and society - “.... a state, attained as a result of joint, purposeful measures implemented by the State and society, in which the independence of the State, its constitutional structure and territorial integrity, the prospect of free development of society, welfare and stability are guaranteed" (Saeima, 2002a, a.1). 
National security and state defence strategies (or concepts) commonly define basic assumptions and actions for maintaining and promoting national security and state security. In the case of Latvia, these are the national security concepts and state defence concepts. The first covers a wide spectrum of security issues (including non-military) and therefore "... determines the basic strategic principles and priorities for the prevention of danger to the State," whereas the latter focuses on military issues as it "...determines the basic strategic principles, priorities and measures of the State military defence during peacetime, danger to the State and a state of war." Both are based on analysis prepared by the state security institutions - the Analysis of Danger to the State and the Analysis of Military Threat respectively (Saeima, 2002a, a.27, 29).

Since 2000s, both documents, respectively security and defence concepts, are approved by Saeima, the Parliament (prior to that - by the Cabinet of Ministers and the National Security Council). The parliament has the right to introduce changes in the version put forth by the government. The National Security Concept is prepared by the Cabinet of Ministers, or more specifically by the Ministry of Interior (2019) and reviewed by the National Security Council. The State Defence Concept is prepared by the Ministry of Defence and reviewed by the Cabinet of Ministers. Both documents have to be approved in every four-year term of the parliament - in the first and the second year of the term accordingly (Saeima, 2002a, a.27, 29).

Hitherto seven editions of the National Security Concept have been approved - in 1995 (Cabinet of Ministers, 1995a), in 2002 (Saeima, 2002b), in 2005 (Saeima, 2005), in 2008 (Saeima, 2008a), in 2011 (Saeima, 2011), in 2015 (Saeima, 2015), and in 2019 (Saeima, 2019). In the same period of time, also seven editions of the State Defence Concept were approved - in 1995 (Cabinet of Ministers, 1995b), in 2001 (Saeima, 2001), in 2003 (Saeima, 2003), in 2008 (Saeima, 2008b), in 2012 (Saeima, 2012), in 2016 (Saeima, 2016) and in 2020 (Saeima, 2020).

Given the aforementioned, the securitizing actor is the state (the Republic of Latvia) in the form of institutions representing it (state security institutions and ministries as bureaucratic structures, as well as the Cabinet of Ministers, the National Security Council and the Parliament as collegiate organizations). The documents emerge as a result of inter-institutional interaction processes among those mentioned above and along with others (e.g., other ministries and institutions or non-governmental players taking part in discussing the draft documents). As the initial drafting process is not public, it is not entirely clear as to what is the precise role of one or the other institution (i.e., interaction of ministries and related institutions and their internal structures and role of individuals).

In terms of securitization, at least two target audiences can be identified. First, the society of Latvia as the documents become publicly available and their main points are communicated to the society by the state institutions and mass media. Second, as both documents are translated and communicated beyond Latvia, it is the international society at large, and allied countries along with others (also the securitized ones) in particular.

\section{DISCUSSION - SECURITIZATION AND DESECURITIZATION OF RUSSIA IN THE NATIONAL SECURITY AND DEFENCE CONCEPTS OF LATVIA}

What follows, is an analysis of all fourteen Latvian national security and state defence concepts approved to the date. The section identifies and assesses securitization moves vis-à-vis Russia as the implied threat to the national security.

In order to reveal the key developments and characteristics of securitization process, the current section is further organized in four sub-sections. It starts with a methodological outline and a quantitative review of securitization and desecuritization of Russia in the concepts of Latvia (section 4.1). Then it proceeds to the review and analysis of securitization and desecuritization across the fourteen documents, further split in three continuous sub-sections. These sub-sections are organized over the lines of three distinct periods of 
national security environment: from 1995 to 2003, covering the concepts issued before Latvia's accession to the European Union (hereafter - EU) and the North Atlantic Treaty Organization (hereafter - NATO) - a period characterized by avoidance to securitize Russia along the road to the Euro-Atlantic structures (section 4.2); from 2005 to 2012, covering the concepts issued after Latvia joined both international organizations - a period characterized by both initial avoidance to securitize Russia right after the accession to EU and NATO and a mix of desecuritization and securitization moves after the 2008 Russian-Georgian military conflict and economization and pragmatization attempts of Latvia's engagement with Russia (section 4.3); and, finally, from 2015 to 2020, covering the concepts issued in the so-called post-Crimea security environment that transcended into a widespread securitization of Russia (section 4.4).

\subsection{The methodological approach in classifying securitization and desecuritization of} Russia in the national security and state defence concepts of Latvia

The following Figure 1 maps the number of mentions of Russia in all national security and defence strategic documents of Latvia since 1995. According to the criteria advanced by the authors, a mention of Russia is classified as securitizing if the securitized subject (Russia) is presented in security context and in a negative form - as a threat to the national security, preferably (from the analytical perspective) with a call to take measures to mitigate the threat. A mention of Russia is classified as desecuritizing if the securitized object is described in a neutral or positive form and as an opportunity and/or necessity for engagement and cooperation. Finally, a mention is classified as nonsecuritizing if it is described purely neutrally and as a contextual factor or subject - neither as a clear risk, nor an opportunity (seemingly neutral mentions in negative and thus securitizing contexts are classified among securitizing ones).

For the ensuing analysis, national security and state defence concepts in the original language, Latvian, are studied in order to ensure consistency and precision. Even though some of these documents have an official English translation, official translations of others have not been identified.

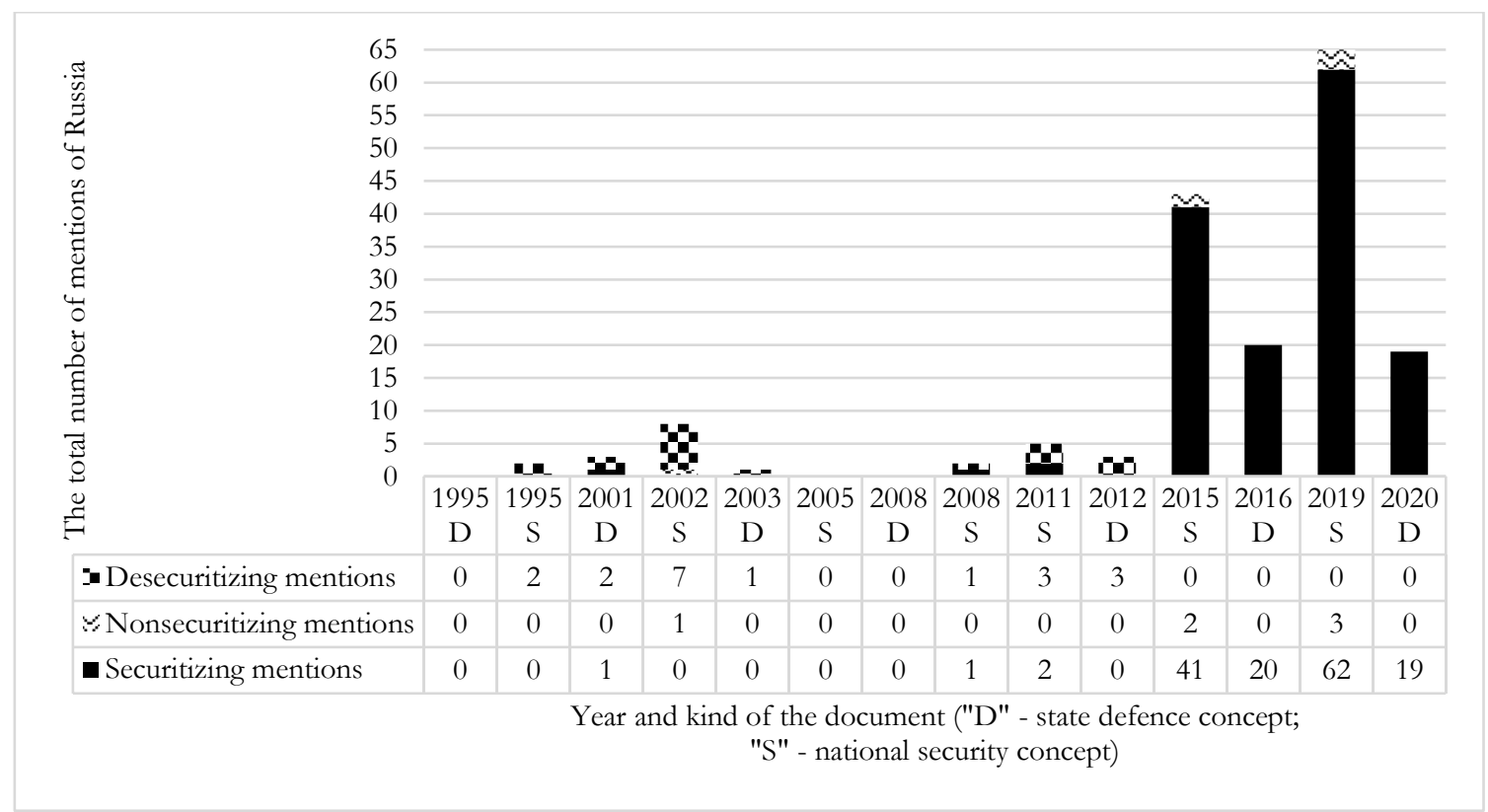

Figure 1. Securitization and desecuritization of Russia in the national security and defence concepts of Latvia from 1995 to 2020

Source. Cabinet of Ministers, 1995a, 1995b; Saeima, 2001, 2002b, 2003, 2005, 2008a, 2008b, 2011, 2012, 2015, 2016, 2019, 2020. 
On the one hand, this presentation of data should be treated with a degree of caution. Purely quantitative approach in identifying mentions of securitized subjects (threats) has its limitations as the number of mentions might or might not precisely reflect the intensity of securitization or desecuritization. First, the securitized object (threat) might be mentioned in texts in a roundabout way, e.g., by using other phrases. Second, some mentions are used in a context of stronger language, while others include milder wording. Third, length and style of the documents differs and thus the place of the mentions of securitized subjects (threats). Fourth, desecuritization can occur also by intentionally avoiding speaking about the securitized object (Wæver, 1995, p.60), and thus the lack of mentions can be considered as desecuritization per se. Fifth, some mentions provide difficulties in drawing a clear line between either securitizing, nonsecuritizing or desecuritizing ones. Sixth, possibly, in some cases, securitization or desecuritization was unintentional, i.e., the final text resulted from compromises of contrasting proposals.

On the other hand, and as explained in the sub-sections that follow, the number of mentions of Russia generally well corresponds to the ups and downs in Latvian-Russian relations. Also, visualization of data in a single figure helps to reflect the general identifiable trends of securitization and desecuritization dynamics. Furthermore, to mitigate and elaborate issues mentioned in the previous paragraph, the following subsections address them in further detail.

\subsection{Securitization and desecuritization of Russia in the national security and state defence concepts of Latvia, 1995-2003}

The first defence and security concepts of Latvia were adopted in 1995. It was the year when Latvia formally set its course towards accession to the EU and NATO and a year after the withdrawal of the armed forces of Russia (the Skrunda Radio Location Station continued its operation until 1998). Thus, Latvia's national security and defence context was primarily determined by the road towards the EU and NATO. As a part of that, Latvia faced expectations from the EU, NATO and the United States to avoid unnecessary securitization of Russia. It was a difficult balance, particularly underlined by the 1998 events in Riga when police adjourned by force a non-sanctioned protest of (mainly) Russian-speaking pensioners. Russia retaliated with blunt criticism and informal economic sanctions.

In the aforementioned context, the first national security and state defence concepts do not securitize Russia. While the defence concept even does not mention Russia by its name (Cabinet of Ministers, 1995b), the security concept mentions it twice. First, it does so by seeking to "maintain normal neighbouring relations with Russia and other CIS states [Commonwealth of Independent States]" in the context of Latvia's Euro-Atlantic integration. Second, by seeking the involvement of Russia (along international organizations) in efforts to avoid incidents regarding the operation of Skrunda Radio Location Station (Cabinet of Ministers, 1995a, ch.4.1, 4.5).

The next editions of both documents were approved on the eve of Latvia's NATO and EU accession (these are the state defence concepts of 2001 and 2003, and the national security concept of 2002). These documents do mention Russia. The state defence concept of 2001 mentions it three times in three continuous sentences: desecuritizing it with mentioning the road towards a market economy and democratic society in Russia and reduction of its armed forces, while ostensibly securitizing it with a mention of instability and difficulties in anticipating its further development path (Saeima, 2001, ch.2).

The next, the 2002 national security concept, includes eight mentions of Russia (most of them in conjunction with Belarus). This document provides difficulties in drawing a clear line between nonsecuritization and desecuritization mentions. A mention of the 1998 economic crisis in Russia in the context of Latvian economy can be considered as a fairly nonsecuritizing. Meanwhile, other mentions speak of Russia as a part of the regional cooperation, importance of its further development path to Latvia, the 
attained bilateral legal base (described as having contributed to the regional security), as well as the need to reach further intergovernmental agreements and border demarcation (Saeima, 2002b, ch.2.1, 2.2.3, 3.1, 3.2.5).

Finally, the 2003 state defence concept mentions it once and it can be interpreted as desecuritizing. It underlines Russia among NATO partners, cooperation with whom "...promotes trust, security, stability and openness in Europe" (Saeima, 2003, ch.3.4.4).

\subsection{Securitization and desecuritization of Russia in the national security and state defence concepts of Latvia, 2005-2012}

Latvia joined both the EU and NATO in 2004. Membership in both organizations, NATO in particular, amid the perceived lack of threat from Russia initially encouraged a new sense of security. While Latvia's armed forces refocused from military territorial defence to expeditionary military capabilities, between 2005 and 2007 Latvia's President and Prime Minister travelled to Moscow, and the border agreement between both countries was completed. Hence, the first national security concept of Latvia in the status of NATO and EU member (issued in 2005) does not mention Russia a single time (Saeima, 2005), and so does the first state defence concept in the status of NATO member (Saeima, 2008b).

The rapprochement with Russia was challenged by the increasingly assertive Russia's foreign policy culminating then with the 2008 Russian-Georgian war. While the war was widely conceived as a concussion to the regional security, it had only short-term effect on Latvia's security and defence policy, partly illustrated by the 2008 national security concept that was not updated to assess the consequences of the war. Though formally adopted by the parliament in October 2008, this document was examined by the National Security Council before the Russian-Georgian war of August 2008 (Saeima, 2008c). It mentions Russia twice. On the one hand, finalization of the border agreement with Russia is underlined as "... establishing a qualitative improvement of security environment of Latvia." On the other hand, Russia's decision to suspend the implementation of its obligations under the Treaty on Conventional Armed Forces in Europe is seen as contributing to "...the reduction of mutual trust and predictability..." (Saeima, 2008a, introduction, ch.1).

One of the main reasons for the continued pragmatization and economization of Latvia's approach to Russia was the global economic and financial crisis, as well as the so-called reset of the US-Russia relations in 2009. Two further visits of the president of Latvia to Moscow in 2010 serve as examples of Latvia's perception of the external security environment of that time.

The following national security concept of 2011 mentions Russia five times. It sends mixed signals. On the one hand, it somewhat securitizes Russia with mentions of the 2008 military conflict in Georgia and Russia-Belarus military exercises as "...events casting doubts about the intentions of neighbouring countries," along with a reference to Russia's self-defined animosity towards NATO. On the other hand, the importance of mutual trust and further NATO-Russia engagement as "... a factor to international security promotion" is stressed (Saeima, 2011, ch.3.1).

To conclude this period, the 2012 state defence concept mentions Russia three times. All of them seem to be aimed at desecuritizing it. The document describes cooperation with Russia as "an aspect that contributes to the strengthening of stability and security of the Baltic Sea region," and it calls for promotion of transparency and trust, as well as limited military cooperation with it and involvement of it in the exercises that are open to NATO partners (Saeima, 2012, ch.48). 


\subsection{Securitization and desecuritization of Russia in the national security and state defence concepts of Latvia, 2015-2020}

The remaining Latvia's national security and state defence concepts take a different twist as result of the Russia-Ukraine conflict. The conflict shattered the European security environment. Security and defence policy of Latvia was no exception. Russia came to dominate most aspects of national security concerns of Latvia. Accordingly, threats from Russia obviously occupy the core of the remaining documents. The first of them, the 2015 national security concept, names Russia 43 times, commencing with a statement that "Russia's aggression in Ukraine has created significant challenges to the European security and global international order." Implications of the conflict in Ukraine are further elaborated both in the description of the security environment and in the actions to be taken by Latvia. In characterizing actions of Russia, its progress in military capabilities and readiness is stressed along with its use of intricate means in pursuit of its foreign policy objectives, intentional creation of devious conflict areas in its direct vicinity, also internal presentation of NATO as its adversary, as well as the influence efforts of Russia in Latvia (Saeima, 2015, ch.3).

Remaining on the 2015 security concept, among the tasks set forth by the concept, Russia implicitly dominates most of the areas: countering foreign intelligence ("...the greatest danger is posed by intelligence agencies of Russia"), countering military threats ("Russia's ... [actions] necessitate a comprehensive approach to the evasion of the threat"), countering threats to the unity of population (e.g., "...Russia intentionally splits the Latvian society..."), threats to the information space (e.g., "Russia's ... [actions] are the main external threat to the information space of Latvia..."), and threats in the cyberspace. In regard to economic threats, Russia in named twice, in the context of its economic downturn and trade restrictions. Both can be interpreted as nonsecuritizing mentions as Russia is not presented as an existential threat, while mitigation of the situation is proposed not by counteractions to it, but by deviation of external economic vectors of Latvia. Finally, while not naming Russia, risks with regard to it are mentioned as notable issues in the areas of internal security, as well as the energy and cargo transport flows (Saeima, 2015, ch.4.1-4.6, 4.8).

The 2016 state defence concept mentions Russia 20 times. All of them directly or indirectly securitize it, commencing that "Russia's aggression in Ukraine" has caused a "concussion of the European security environment" and stressing that thus "...Russia ruins the existing international order". The document proceeds with such takes on Russia as the promotion of hostility to NATO and EU countries in the Russian society, other military activities of Russia outside its borders, display of its military force, enhancement of its armed forces, and increase of threats from Russia across various fields, including the information space, cyberspace, energy and economics. Mentions of Russia conclude with an unambiguous hint at the military threat it poses - "...Russia develops and exercises capabilities that can be used to launch an unexpected military assault against the Baltic states..." (Saeima, 2016, ch.5-10, 12-13).

The current national security concept of 2019 mentions Russia 65 times. This document tops the list of all those since 1990s both in terms of the number of mentions and the intensity of securitization of Russia. Russia is named in every single section of the concept, except the one devoted to the international terrorism. Similar to the previous concept, Russia is securitized across a wide spectrum of national security issues. The document underlines that "[t]he military dimension [of the national security of Latvia] is characterized by military activities of Russia in the Baltic region and also other hybrid form security risks and threats directed against Latvia" (Saeima, 2019, ch.1-9).

Apart from characterization of the 2019 concept itself and the national security and the external environment, Russia is further securitized in chapters on countering military threats (e.g., "... its employed aggressive security policy in the Baltic region is considered the main source of threats to the national security of Latvia"); on countering foreign intelligence (e.g., "[t]he most significant threat to the collective security 
of NATO and EU member states and to the national security and interests of Latvia are posed by the intelligence services of Russia”); on countering cyber-threats (“...Russia extensively uses the cyberspace not only for espionage, but also for conducting information operations and destructive actions"); on countering threats to the internal security (e.g., "Russia uses compatriots' policy as an instrument for involving compatriots in influence activities of Russia that are directed against the national security of Latvia"); on countering threats to the information space (e.g., "[t]he main external threat to the information space of Latvia is the informative policy employed by Russia aimed at ruining political, economic and social sustainability and stability of Latvia...") (Saeima, 2019, ch.4-8).

Similar to the national security concept of 2015, also the current one from 2019 mentions Russia in the chapter devoted to countering of the economic threats. Again, it is done in a fairly descriptive and nonsecuritizing manner regarding Russia's supply of natural gas and its cargo transit policy (Saeima, 2019, ch.9)). Russia is here presented as a source of economic uncertainty, though not as an existential threat.

The remaining document - the current state defence concept of 2020 - mentions Russia 19 times. Russia's name dominates the security environment's sub-chapter on regional trends (it contains all but one of the mentions). Russia is slammed for its "defiant and aggressive military and hybrid activities". It is detailed that the country attempts to influence domestic processes elsewhere, while at home dissidents are persecuted ever more. It is concluded that for Russia “...everything that brings no punishment or response is licit". It is also argued that for domestic consumption it will continue portraying itself as "an entrenched fortress," while negative Latvia's image there will be further facilitated (Saeima, 2020, ch.1.2).

On a more military note, Russia's advancements in capabilities directed westwards are underlined, and, it is assumed, the most likely military action plots are "hybrid war and sudden attack". Furthermore, Russia's readiness to threaten or even to use nuclear weapons is underlined (Saeima, 2020, ch.1.2). Finally, Russia's name is invoked in the sub-chapter of conventional defence of Latvia. There, its military advancement serves as a reason for emphasizing the need to advance early warning systems (Saeima, 2020, ch.3.1.1.1).

\section{RESULTS AND CONCLUSIONS}

Review of the Latvian national security and defence concepts from three decades provides a structured insight in a state-level approach to securitization. It illustrates how one country, in this case Russia, has been securitized and desecuritized in the documents that are intended to determine the framework of national security and state defence. Even though the applied approach, combining quantitative and qualitative content analysis, has its limitations (like risking omitting, misinterpreting, emphasizing or downgrading some nuances), it provides a different angle on the dynamics of state-level securitization processes.

The analysis of Russia in the aforementioned documents points to that the documents are largely a reflection of the security situation of the time of their approval. These documents reflect the institutional and political perceptions and decisions in the domestic and international context of that time. Hence, most of Latvia's national security and state defence concepts (up until the Ukraine crisis) have been limited in their pre-emptive and future-proof nature (at least regarding Russia). This is not to say that future trends can be always foreseen. Rather, that, despite lessons from history, prevailing trends and vast literature on Russia, the national security and state defence concepts have not used the potential of all available expertise. Put in terms of securitization, if a referent object (in this case Latvia) is existentially threatened by another object that in similar forms has been there in the past and has previously created existential threats (in this case Russia and its legal predecessor, the Soviet Union), then this should logically be seen an objective existential threat and should also be securitized. As our analysis demonstrated, this has not always been the case. Can an existential threat from the same source disappear and then again reappear? Or rather it was intentionally or unintentionally neglected, or essentially undersecuritized? 
To elaborate the aforementioned point in empirical terms, after having regained independence from the Soviet Union and the withdrawal of Russian armed forces in 1991 and 1994 respectively, national security and state defence concepts from the mid-1990s and early 2000s demonstrated cautiousness in regard to Russia - mainly avoiding securitizing, or desecuritizing it. This approach can be in part explained by the fragility of the security and external environment - having an operating Russian military installation in Latvia until 1998 and being on the road to the EU and NATO at the time when the Western partners tried to engage with Russia.

Similar trends ensued after Latvia joined the EU and NATO in 2004. The first two documents in the new status even did not address Russia by name. The 2008 Russo-Georgian war was a concussion to the perception of security situation in Latvia and beyond, though it peculiarly did not receive any attention in the first national security concept after that war. The 2008 war had no fundamental impact on security policy making for the years to come (not only exemplified by the security and defence concepts, but also by the following neglect of the Latvian armed forces, among many other examples). Even though the 2008 war led to securitization of Russia in the national security concept of 2011, the state defence concept of 2012 went on again over a Russia-desecuritizing path.

Approaches and patterns changed rather fundamentally with Russia's aggression in Ukraine. It left visible impact at all levels of national security and state defence policy, including the national security and state defence concepts from 2015 and on. It was perceived as a strategic and security wake-up call for decision-makers and society alike. The surge of securitization of Russia was evident, as presented in Figure 1 , even raising questions of a possible oversecuritization at the expense of other security issues. This leads us to possible lessons learned for the future national security and defence concepts. Most notably, it would be advisable to maintain a broad vision of the national security and state defence approach. And there is the task to identify and essentially securitize (but not necessarily oversecuritize) objective risks and threats notwithstanding short-term domestic or international exigencies.

\section{REFERENCES}

Buzan, B., \& Hansen, L. (2009). The evolution of international security studies. Cambridge: Cambridge University Press.

Buzan, B., Wæver, O., \& de Wilde, J. (1998). Security: A new framework for analysis. Boulder: Lynne Rienner.

Cabinet of Ministers. (1995a). Nacionālās drošizas koncepcija [National Security Concept], https://www.vestnesis.lv/ta/id/35935 (accessed: 20 May 2020).

Cabinet of Ministers. (1995b). Latvijas Republikas aizsardzibas koncepcija [State Defence Concept of the Republic of Latvia], https://www.vestnesis.lv/ta/id/35936 (accessed: 20 May 2020).

Hansen, L. (2000). The Little Mermaid's silent security dilemma and the absence of gender in the Copenhagen School. Millennium, 29(2), 285-306.

Hansen, L. (2011). Theorizing the image for security studies: Visual securitization and the Muhammad cartoon crisis. European Journal of International Relations, 17(1), 51-74.

McDonald, M. (2008). Securitization and the construction of security. European Journal of International Relations, 14(4), $563-587$.

Ministry of Interior. (2019). Nacionālajā drošibas koncepcijā nosaka Latvijas prioritātes ar valsts drošìbu saistīto apdraudējuma noveršanai [National Security Concept Determines Latvia's Priorities Related to the Prevention of Threats to the State Security], http://iem.gov.lv/lat/aktualitates/informacija medijiem/?doc=42229 (accessed: 20 May 2020).

Roe, P. (2004). Securitization and minority rights: Conditions of desecuritization. Security dialogue, 35(3), $279-294$.

Saeima. (2001). Par V alsts aizsardzibas koncepciju [On the State Defence Concept], https://likumi.lv/ta/id/224770-par-valstsaizsardzibas-koncepciju (accessed: 20 May 2020).

Saeima. (2002a). National security law, https://likumi.lv/ta/en/en/id/14011-national-security-law (accessed: 20 May 2020). 
Saeima. (2002b). Par Nacionäläs drošibas koncepcïu [On the National Security Concept], https://likumi.lv/ta/id/227208-parnacionalas-drosibas-koncepciju (accessed: 20 May 2020).

Saeima. (2003). Par V alsts aizsardzibas koncepciju [On the State Defence Concept], https://likumi.lv/ta/id/228302-par-valstsaizsardzibas-koncepciju (accessed: 20 May 2020).

Saeima. (2005). Par Nacionālās drošibas koncepciju [On the National Security Concept], https://likumi.lv/ta/id/217772-parnacionalas-drosibas-koncepciju (accessed: 20 May 2020).

Saeima. (2008a). Nacionālās drošibas koncepcija [The National Security Concept], https://www.vestnesis.lv/ta/id/182987 (accessed: 20 May 2020).

Saeima. (2008b). Par V alsts aizardzibas [sic] koncepciju [On the State Defence Concept], https://likumi.lv/ta/id/177839-parvalsts-aizardzibas-koncepciju (accessed: 20 May 2020).

Saeima. (2008c). Rìgā 2008.gada 23.septembrì, Nr.9/15- In Riga, on 23 September 2008, No.9/15-7, https://www.saeima.lv/Likumdosana/9S DK/lasa-dd=LM0506 0-1.htm (accessed: 20 May 2020).

Saeima. (2011). Par Nacionālās drošibas koncepcijas apstiprināšanu [On Approval of the National Security Concept], https:/ likumi.lv/doc.php?id=227460 (accessed: 20 May 2020).

Saeima. (2012). Par Valsts aizsardఇৃibas koncepcijas apstiprinäšanu [On Approval of the State Defence Concept], https://likumi.lv/ta/id/248069-par-valsts-aizsardzibas-koncepcijas-apstiprinasanu (accessed: 20 May 2020).

Saeima. (2015). Par Nacionālās drošības koncepcijas apstiprināsanu [On Approval of the National Security Concept], https://likumi.lv/ta/id/278107-par-nacionalas-drosibas-koncepcijas-apstiprinasanu (accessed: 20 May 2020).

Saeima. (2016). Par Valsts aizsardzibas koncepcijas apstiprinäsanu [On Approval of the State Defence Concept], https://likumi.lv/ta/id/282964-parvalsts-aizsardzibas-koncepcijas-apstiprinasanu (accessed: 20 May 2020).

Saeima. (2019). Par Nacionāāss drošības koncepcijas apstiprināsananu [On Approval of the National Security Concept], https://likumi.lv/ta/id/309647-par-nacionalas-drosibas-koncepcijas-apstiprinasanu (accessed: 20 May 2020).

Saeima. (2020). Par Valsts aizsardzibas koncepcijas apstiprinäšanu [On Approval of the State Defence Concept], https://likumi.lv/ta/id/317591-par-valsts-aizsardzibas-koncepcijas-apstiprinasanu (accessed: 20 December 2020).

Wæver, O. (1989). Security, the Speech Act: Analysing the politics of a word. Working Paper no. 1989/19. Copenhagen: Centre for Peace and Conflict Research.

Wæver, O. (1995). Securitization and desecuritization. In R. D. Lipschutz (Ed.). On Security, 46-86. New York, Columbia University Press.

Wæver, O. (1998). Insecurity, security, and asecurity in the West European non-war community. Cambridge Studies in International Relations, 62(1), 69-118.

Wæver, O. (2000). The EU as a security actor: reflections from a pessimistic constructivist on post-sovereign security orders. In M. Kelstrup \& M. C. Williams (Eds.), International Relations Theory and the Politics of European Integration, 250-294. London: Routledge.

Wilkinson, C. (2007). The Copenhagen school on tour in Kyrgyzstan: Is securitization theory useable outside Europe?. Security Dialogue, 38(1), 5-25. 